\title{
Homogeneity, Heterogeneity and Direct Democracy: The Case of Swiss Referenda
}

\author{
ABRAHAM Diskin Hebrew University of Jerusalem \\ ANDRÉ ESCHET-SCHWARZ University of Haifa \\ Dan S. Felsenthal University of Haifa
}

\section{Introduction}

In his famous dichotomy of consensual versus majoritarian democracies, Lijphart (1984) claims that "consensual" means are more applicable in heterogeneous societies, while "majoritarian" means are more adequate in homogenous societies. ${ }^{1}$ While discussing at length many features of both consensual and majoritarian democracy, Lijphart refrains from reaching a conclusion concerning the desirability of conducting referenda in either homogeneous or heterogeneous societies. He argues that referenda "are foreign to both majoritarian and consensual theories," although "they may occur to a certain degree in the practice of both types of democracy" (1984: 197). His findings support this claim. Unlike the other "variables distinguishing majoritarian from consensus democracy," referenda do not fit either type (1984: 214). However, in his more recent work on democracies Lijphart states that, contrary to conventional wisdom-which views referenda as "blunt majoritarian" instrument - referendum-plus-initiative as has worked in Switzerland supports the conclusion that, according to Jung (1996), "it can be seen as a

Acknowledgments: We are grateful to two anonymous reviewers of this Journal for their helpful comments.

Abraham Diskin is associate professor of Political Science at the Department of Political Science, Hebrew University of Jerusalem, Mount Scopus, Jerusalem 91905, Israel. Email: mshanna@pluto.mscc.huji.ac.il

André Eschet-Schwarz is lecturer of Political Science at the School of Political Sciences, University of Haifa, Mount Carmel, Haifa 31905, Israel. Email: rspc303@ poli.haifa.ac.il

Dan S. Felsenthal, is professor emeritus of Political Science at the School of Political Sciences, University of Haifa, Mount Carmel, Haifa 31905, Israel. Email: msdanfl@, mscc.huji.ac.il 
strong consensus-inducing mechanism and a very opposite of a blunt majoritarian instrument" (Lijphart, 1999: 231).

On the one hand, it may be argued that when employing the various tools of direct democracy, especially referenda, voters and groups of voters are more inclined to base their decisions on short-term, particularistic, and egocentric considerations. In a heterogeneous society this inclination may not only reflect but also deepen and reinforce the dividing factors, as do other means of majoritarian democracy, especially when PR-elections are not used. ${ }^{2}$ Thus, for example, when the citizens of Belgium were asked by referendum in 1950 if they approve the return of King Leopold III, the cleavage between the two Belgian linguistic communities - which was quite latent up to this point - revealed its true dimensions (see McRae, 1986: 111-112).

Moreover, critiques of direct democracy often argue, directly or indirectly, that using referenda cannot promote the homogeneity of a society. Thus, Haskell claims that "the 'popular will' cannot be identified with any precision or certainty by taking a vote.... The very idea that the results of a plebiscite should be implemented into public policy is potentially dangerous and illiberal.... In light of our new technological capabilities, constitutional limits on direct democracy actually are now more important than ever before" (2000: 3). Similarly, Gerber (1999) shows that although interest groups with limited public support may be able to defeat proposals, they are unlikely to succeed in referenda in terms of passing proposals, even if they ran extremely expensive campaigns.

On the other hand, it could be argued that employing features of direct democracy, especially referenda, may serve as a moderating instrument in heterogeneous societies. Conflicting groups may thereby express their priorities - and sometime even veto unfavourable policies - rather than slide into harsh clashes. Furthermore, the instruments of direct democracy may reveal the existence of common denominators in the positions of social segments that are otherwise regarded as highly divided, thereby creating a different political culture of large coalitions based on compromises and promote integration of different oppositions within the rules of the game (see Papadopoulos, 1998: 158-159). Moreover, the results of a referendum in a heterogeneous society may serve as a reliable guide for the government regarding the need to abolish some policies to which there is a widespread opposition on one side of the political map. ${ }^{3}$

In view of these arguments, we wish to examine in this study whether the distribution of votes in a pluralistic society which uses measures of direct democracy tends to reflect more the heterogeneous or the homogeneous characteristics of this society. In order to do this we decided to investigate all Swiss federal referenda conducted until the end of 2005 and to analyze the extent of similarity between voting trends in these referenda among the various Swiss cantons. 
Abstract. The general question addressed in this study is whether voting behaviour in referenda conducted in a pluralistic society tends to reflect more the heterogeneous or the homogeneous characteristics of this society. In order to answer this question we investigated, mainly by means of factor analysis, all 538 federal referenda conducted in Switzerland since the foundation of the Swiss Confederation in 1848 until the end of 2005. Based on the extensive Swiss experience, the answer to our question seems quite clearly to be that the use of referenda as tools of direct democracy in a pluralistic society tends to reflect much more the homogeneous characteristics of that society than its heterogeneous ones.

Résumé. Le thème général de l'étude est le suivant: le comportement des votants qui participent aux référendums dans une société pluraliste est-il influencé par les caractéristiques hétérogènes ou homogènes de la société en question? Afin de répondre à cette question nous avons examiné, par analyse factorielle, 538 referendums fédéraux tenus en Suisse depuis la création de la Confédération suisse en 1848 et jusqu'en 2005. Le résultat de notre recherche montre clairement que 1'utilisation des référendums comme instrument de démocratie directe dans une société pluraliste a tendance à refléter davantage les caractéristiques homogènes que les caractéristiques hétérogènes de la société.

Switzerland provides an excellent case for the examination of this question: it is a society distinctly divided along linguistic and religious attributes which are reflected in the composition of its cantons (see, for example, Bartolini, 2000: 186; Bartolini and Mair, 1990: 238; McRae, 1983: 49-92); it conducted a number of national referenda which to date is considerably more than those held in any other country; ${ }^{4}$ and it represents a rare case where the popular initiative is used extensively at the national level (see Setälä, 1999: 73).

The Swiss federation was composed of 25 cantons (or "half-cantons") from its foundation in 1848 until 1979 when the Canton of Jura was created. The creation of Jura was strongly supported by French-speaking cantons and, for a long period of time, strongly opposed by many Germanspeaking Protestant cantons (see Pichard, 2004: 94-95).

Out of the current 26 cantons, German is spoken by the majority of people in 19 cantons, French is spoken by the majority of people in six cantons, and Italian is spoken by the majority of people in one canton. In 14 cantons there is a Catholic majority and in the remaining 12 cantons there is a Protestant majority. With the exception of the single Italianspeaking Catholic canton (Ticino), there is hardly any correlation between the language and the religion of the majority: three of the French-speaking cantons are Catholic and the other three are Protestant; ten of the Germanspeaking cantons are Protestant and nine are Catholic. In this sense, the main social cleavages in Switzerland tend to be "cross-cutting" (see Lipset, 1981: 13). The current distribution of Swiss cantons by the majority's language and religion is presented in Appendix A. ${ }^{5}$ At the same time, the Swiss political system has been characterized, for a rather long period of time, by unique stability and cohesiveness. Perhaps the most prominent indication of these features is the famous Swiss "magic formula." In 1959, the four largest political parties of Switzerland (the Christian Democratic 
People's Party, the Social Democratic Party, the Radical Free Democratic Party, and the Swiss People's Party) who together controlled most of the seats in the federal parliament, reached an informal coalitional agreement dividing the seven federal ministries among them and establishing an annual rotation in the position of the President of the Swiss Confederation who actually serves, in addition to being a minister of one of the seven ministries, also as chairman of the Swiss Federal Council (cabinet) and undertakes special representational duties. So far this agreement has been kept with only slight amendments. ${ }^{6}$

We also investigate the degree of homogeneity and heterogeneity in different types of referenda. We focus on the difference between referenda on constitutional issues and referenda on regular legislative issues. In this framework we also examine the correlation between governmental success in maintaining its position in the various referenda and the relative weight of the homogeneity factor.

In view of the above, we attempt to provide an answer in this study to the following six questions:

(1) Is it possible to discern, overall, a clear tendency of homogeneous or of heterogeneous voting behaviour in Swiss referenda?

(2) Given the two main differences among Swiss cantons-linguistic differences and religious differences-which one may be regarded as the more important (heterogeneous) factor in Swiss referenda?

(3) Have linguistic differences in Swiss referenda become more prominent since the establishment of Jura in 1979?

(4) Has homogeneity in Swiss referenda become more prominent since the implementation of the magic formula agreement of 1959 ?

(5) Is homogeneity in Swiss referenda more prominent in referenda on constitutional issues than on regular legislative issues?

(6) Is homogeneity in Swiss referenda more prominent in referenda whose final outcome is concordant with the government's position than in referenda in which the final outcome is contrary to the government's position?

\section{The Data Set}

Our data set pertains to all federal referenda conducted in Switzerland during the period from September 12, 1848, until November 27, 2005. The official number of referenda conducted during this 157 -year period is 521 , but our data set pertains to 538 referenda. ${ }^{7}$ However, we decided to ignore the first referendum because for this referendum only the total number of "ayes" and "nays" for the entire Swiss federation is known but not also the number of "ayes" and "nays" for each canton. Our analysis and findings for most investigated variables are therefore based on 537 referenda. 
Beginning with the second referendum (conducted in 1866) our data set contains, with respect to each referendum in each of the 25 (or 26) cantons ${ }^{8}$ the following information: serial and official numbers of the referendum, number of eligible voters, ${ }^{9}$ whether voting in the canton was mandatory, ${ }^{10}$ number of voters who voted in favour, number of voters who voted against, the weight of the canton, ${ }^{11}$ the type of the referendum and the date in which it was conducted.

These data are based on two main sources: for referenda $\# 2$ through 19 (conducted during the period 1866-1877) we used the official gazettes (Amtsblatt) of the various cantons, and from referendum \#20 (conducted in 1879) onwards we relied on the information posted on the official website of the Swiss Confederation regarding federal referenda (http://www.admin.ch/ch/d/pore/va/index.html).

\section{Initiatives and Types of Referenda}

According to articles 138-142 of the current Swiss constitution (that entered into force on January 1, 2000, and which amalgamated all amendments to the previous 1848 and 1874 Swiss constitutions), there are two main types of federal referenda.

(1) Referenda initiated by the government. According to the 1848 constitution the government is obliged to conduct a referendum whenever it wishes to amend the federal constitution or to join international organizations of collective security or super-national communities. It must also conduct a referendum whenever it enacts a federal statute that is declared urgent, which has no constitutional basis and whose validity exceeds one year. Such federal statutes must be submitted to a referendum within one year after their adoption by the federal parliament.

(2) Referenda initiated by the citizens. Referenda initiated by the citizens occur only if a minimum number of citizens sign a petition within a specified period of time. There are three sub-types of such referenda.

(2a) A popular initiative to repeal Federal laws, or generally binding decisions of the Swiss Federation or State treaties concluded for an indefinite duration. This type of referenda, also called "facultative referenda," was introduced in 1874. It was then established that 30,000 citizens or the legislatures of eight cantons ${ }^{12}$ can require that a referendum be conducted on a law passed by the federal parliament. Currently a referendum will be conducted on such decrees if at least 50,000 eligible voters or the legislatures of eight cantons so request within 100 days of the publication of the decree in the official gazette. 
(2b) A popular initiative to amend the Federal Constitution. This type of referendum was introduced in 1891. Currently a referendum is conducted on a proposed total or partial revision of the federal constitution if at least 100,000 eligible voters request it.

A popular initiative for a total revision of the federal constitution must be submitted to a vote of the people only. ${ }^{13}$ If a majority of the voters agrees, the federal parliament is dissolved and an assembly is elected to draft a new constitution. The resulting document is then submitted to a referendum, in which it must gain a majority of both the people and the cantons (see Linder, 1998: 87).

A popular initiative for a partial revision of the federal constitution may be in the form of a general suggestion or in the form of a detailed proposal. In the former case the (general) proposal must first be discussed by both chambers of the federal parliament; if both chambers approve it then a detailed proposal is drafted accordingly by the parliament and submitted to a vote of both the people and the cantons, ${ }^{14}$ but if at least one chamber rejects it then the proposal is submitted to a vote of the people in order to decide only whether to proceed with a detailed proposal. ${ }^{15}$

In the latter case-which is the most common-the (detailed) proposal for partial amendment of the constitution is submitted to a vote by the people and the cantons. The federal parliament recommends whether to approve the proposal. If it recommends its rejection, it may submit its own counterproposal on the same ballot on which the original (popular) proposal appears. Until 1987 there were 13 occasions in which the government submitted a counterproposal to a popular initiative. ${ }^{16}$ In all these occasions it was not possible for voters to vote in favour of both the popular initiative and the governmental counterproposal. However, in 1987 the constitution was amended and it became possible for voters to vote in favour of both these options; consequently, on the two occasions in which this has happened till the end of $2005^{17}$ the voters could respond also to a "deciding question" by stating whether the popular initiative or the governmental counterproposal should be adopted in case both secured the required (double) majority for passage. So far there were also 18 occasions where a popular initiative was withdrawn after the government submitted its counterproposal and the subsequent referendum was conducted only on the counterproposal. ${ }^{18}$

Under all referenda types, a sufficient condition for a proposal to be rejected is that the overall majority of the voters vote against it. In referenda of type $2 a$, and some categories of type $2 b$, a necessary and sufficient condition for a proposal to pass is that it is approved by an overall majority of the voters. However, in referenda of type 1 and the major category of type $2 \mathrm{~b}$ a proposal must be approved by a double majority: a 
majority of the valid votes cast throughout the country as well as by the majority of the cantons' votes. ${ }^{19}$ As is shown in the bottom of Appendix B, of all referenda of types 1 and $2 \mathrm{~b}$ conducted until the end of 2005, only in eight of them (six of type 1 and two of type $2 b)^{20}$ the overall majority of voters supported the proposal while the majority of the cantons voted against it.

2c. A general popular initiative. In a referendum conducted on February 9, 2003, the Swiss voters affirmed an amendment to the constitution proposed by the government whereby a general popular initiative will be available to Swiss voters. At the time of writing this amendment has not yet entered into force. The mechanism of the general popular initiative - which is described in Article 139a of the current Swiss constitution (see also Church (2004: 230-231) — can be used to force a referendum on the adoption of a general proposal (as distinct from a detailed proposal) demanding to change or abolish provisions of the federal constitution or statutes provided that 100,000 signatures of citizens entitled to vote are collected in support of the initiative. Once the general popular initiative is implemented, the popular initiative for a partial revision of the constitution will only be accepted in the form of a written text proposition, while general propositions in relation to the constitution will be made using the general popular initiative.

\section{Findings}

In order to be able to identify factors underlying the results of the various Swiss referenda, we constructed a table having 537 lines (one line for each referendum) and 28 columns (one column for each of the 26 cantons, one column for the type of the referendum and one column for the final overall result of the referendum). In each cell of the first 26 columns of this table we listed the percentage of voters of the particular canton who voted "yes" on the particular referendum. ${ }^{21}$

Table 1 presents score coefficients and communalities of the 26 Swiss cantons based on factor analysis (principal component analysisthree orthogonal factors) ${ }^{22}$ of all 537 referenda examined in this study. The communalities obtained are very high for all cantons: with the exception of Ticino (the Catholic Italian-speaking canton with communality 0.791) and Uri (a Catholic German-speaking canton with communality 0.867 ), all communalities are higher than 0.9 .

The first factor (factor I) presented in Table 1 accounts for 84.6 per cent of the observed variance. This factor should therefore clearly be interpreted as the "homogeneity factor" because the score coefficients of all cantons for this factor, with the exception of Jura (0.681), are higher than 0.8 . We conducted similar analyses for the three different types of refer- 
TABLE 1

Score Coefficients and Communalities of Cantons Based on Factor Analysis (Principal Component Analysis) of Three Orthogonal Factors

\begin{tabular}{lcccc}
\hline \hline & & \multicolumn{3}{c}{ Second } \\
& $\begin{array}{c}\text { Homogeneity } \\
\text { Factor }\end{array}$ & $\begin{array}{c}\text { Language } \\
\text { Factor } \\
\text { (Factor I) }\end{array}$ & $\begin{array}{c}\text { Heterogeneity } \\
\text { Factor } \\
\text { (Factor II) }\end{array}$ & $\begin{array}{l}\text { (Factor III) } \\
\text { Communalities }\end{array}$ \\
\hline Zürich & 0.959 & -0.095 & -0.214 & 0.974 \\
Bern & 0.965 & -0.064 & -0.153 & 0.960 \\
Glarus & 0.946 & -0.250 & -0.019 & 0.958 \\
Basel-Stadt & 0.894 & 0.081 & -0.396 & 0.962 \\
Basel-Land & 0.959 & 0.005 & -0.228 & 0.971 \\
Schaffhausen & 0.958 & -0.132 & -0.103 & 0.946 \\
Appenzell A.-Rh. & 0.954 & -0.245 & -0.012 & 0.970 \\
Graubünden & 0.967 & -0.100 & 0.006 & 0.945 \\
Aargau & 0.967 & -0.158 & -0.012 & 0.960 \\
Thurgau & 0.956 & -0.221 & 0.064 & 0.966 \\
Luzern & 0.979 & -0.098 & 0.051 & 0.970 \\
Uri & 0.915 & -0.162 & 0.064 & 0.867 \\
Schwyz & 0.937 & -0.197 & 0.192 & 0.953 \\
Obwalden & 0.954 & -0.128 & 0.179 & 0.959 \\
Nidwalden & 0.967 & -0.154 & 0.111 & 0.970 \\
Zug & 0.962 & -0.087 & -0.006 & 0.934 \\
Solothurn & 0.966 & -0.090 & -0.104 & 0.952 \\
Appenzell I.-Rh. & 0.909 & -0.303 & 0.185 & 0.953 \\
St. Galen & 0.972 & -0.201 & 0.001 & 0.985 \\
Vaud & 0.845 & 0.462 & 0.074 & 0.933 \\
Neuchâtel & 0.821 & 0.536 & -0.007 & 0.960 \\
Genève & 0.804 & 0.527 & -0.153 & 0.947 \\
Fribourg & 0.914 & 0.336 & 0.133 & 0.967 \\
Valais & 0.840 & 0.298 & 0.363 & 0.926 \\
Jura & 0.681 & 0.666 & 0.062 & 0.911 \\
Ticino & 0.853 & 0.247 & -0.037 & 0.791 \\
\hline & & & &
\end{tabular}

enda. In all these analyses the homogeneity factor proved to be the most decisive and the score coefficients of each and every canton for this factor were higher than the canton's score for any other factor. Given these results it is obvious that the answer to our first question is that, overall, a very strong tendency of homogeneous voting behaviour is indeed displayed in Swiss referenda. An apparently reasonable explanation for this finding is that referendums will tend to be on issues on which one would expect a more homogenous response. We cannot verify this explanation, as we did not analyze the various referenda by topic. Furthermore, while it is possible to analyze whether topics of actual referenda were more or less homogeneous, one can only speculate as to why other topics were not subject to referenda. In addition, such an explanation is questionable 
given the fact that the number of referenda that failed (281) is larger than the number of successful referenda (256). An alternative partial explanation to this finding is an increase with time in both the proportion of referenda of type $2 b$ as well as the rate of their rejection (see Tables 5 and 6).

There are alternative methods by which one can demonstrate this homogeneity tendency. Thus, for example, all cantons have voted in the majority of the 537 referenda in a way identical with the overall final outcome of the referenda (see the last column of Appendix A). This finding holds also when each of the three types of referenda is examined separately (see columns 1, 2, 5, 6, 9, 10 in Appendix B). When referenda are divided into six subgroups according to both type and a positive or negative final result, we found that out of 156 cases (26 cantons $\times 6$ subgroups) only three exceptions to this rule occurred: canton Zürich, canton Basel-Stadt, and canton Jura, with only 41.3 per cent $(19 / 46 \times 100), 47.8$ per cent $(22 / 46 \times 100)$, and 43.75 per cent $(7 / 16 \times$ $100)$, respectively, of the cases where the majority of voters voted "no" when a "no" final overall outcome was obtained in type-1 referenda (see columns 2 and 3 in Appendix B). The mean result of these 156 calculations is 81.7 per cent.

From Table 1 and Appendix A it is clear that the answer to our second question is that linguistic differences among cantons are the most important heterogeneous characteristic. Factor II (called "language" in Table 1) accounts for 7.7 per cent of the observed variance. As can be seen in Table 1, the score coefficients of all French-speaking cantons, as well as the Italian-speaking canton, are positive on this factor, with a range of 0.247 (Ticino) to 0.666 (Jura). On the other hand, except for two German-speaking cantons (Basel-Stadt and Basel-Land) all the scores of the remaining German-speaking cantons are negative on this factor. The gap between the two main linguistic communities was essentially attributed to the existence of differences regarding certain foreign policies - mainly the adoption of more openness towards the outside world - as well as about adopting measures that could strengthen federal authority and restrict the resources of the cantons or individual liberties (see Kriesi et al., 1996: 36).

In all factor analyses conducted for six subgroups of referenda (by type and final result), the same order of scores was obtained for both factor II (language) and factor III. The importance of linguistic differences as a significant heterogeneity factor can also be demonstrated through alternative methods. Thus, we also examined, for all six sub-groups of referenda, the Pearson coefficients of linear correlation between the proportions of "yes" votes for all pairs of cantons. We found that the Pearson coefficients between pairs of cantons that share the same (majority) language are usually higher than coefficients between pairs of cantons where 
the majority of citizens speak different languages. Similarly, as can be seen from the last column of Appendix A, all but three German-speaking cantons ranked higher than the French- and Italian-speaking cantons in the percentage of times their vote was concordant with the final outcome.

Factor III in Table 1 accounts for only 2.3 per cent of the variance. As can be seen from Table 1 and Appendix A, it tends to be associated with religion, but there are more deviations from this association (7) as compared to the number of deviations (2) from the linguistic factor (where all but two of the German-speaking cantons have negative score coefficients while all the Italian- and French-speaking cantons have positive score coefficients). Regardless of their linguistic affiliation, 9 of the 12 Protestant cantons have negative score coefficients on factor III, while 10 of the 14 Catholic cantons have positive scores. Similar tendencies were identified in factor analyses conducted on the six subgroups of referenda. Because more deviations are associated with this factor, we are somewhat reluctant to definitely call it "religion" and prefer to refer to it more vaguely as the "second heterogeneity factor," ${ }^{23}$ this despite the fact that the deviations seem quite minor: Catholic cantons never obtained scores lower than -0.153 whereas Protestant cantons never obtained scores higher than 0.074 . However, as can be observed from Table 2, it should be emphasized that the second heterogeneity factor accounted for a higher proportion of the observed variance than that accounted for by the linguistic factor in the period preceding the creation of canton Jura.

In some way, these factors represent a summary of the essential features of Swiss political behaviour in referenda. It is the representation of the major features and cleavages of the Swiss society from the midnineteenth century to the beginning of the twenty-first century. We are aware that such a global picture of the Swiss political behaviour, over one and half centuries, can conceal some of the major conflicts related to Swiss society. Scholars who analyzed the traditional cleavages and the new social movements noticed at least four cleavages with differentiated saliency: centre and periphery, religious, and urban-rural cleavages as well as the cleavage between the working class and the bourgeoisie (Kriesi et al., 1995: 10-16). The fact that most of the referenda took place after the Second World War explains the fact that some of those cleavages did not appear in our factor analysis. One can add the insight that where the religious and linguistic cleavages are salient, the class cleavage becomes problematic in manifesting itself in the same magnitude as in homogeneous countries. Bartolini found a negative correlation between votes for the left and linguistic and religious heterogeneity in European countries. Until the 1920s the religious element produced the negative association, while from the 1930s onwards, language plays this role (Bartolini, 2000: 191). Our results about Switzerland confirm this statement. 
Table 3 presents the percent of variance explained by our three factors before and after the introduction of the magic formula agreement.

As can be seen in Tables 2 and 3, the percent of variance accounted for by factors I and II, as well as the total variance accounted for by the three factors together, is higher in the "after" period than in the "before" period. However, the opposite is true for factor III, which accounts for a higher percentage of the variance in the "before" than in the "after" periods in both these tables. It should also be noted that despite the fact that the canton Jura was established 20 years and 106 referenda after the institution of the magic formula, the percentages in the "after" periods in both Tables 2 and 3 are identical. Moreover, when all 537 referenda are included in the factor analysis, the percentage of the variance accounted for by each of the three factors, as well as by all of them together, is exactly the same as the respective percentages listed in the "after" period in Table 2. The obvious conclusion is that at least one of these two events (the introduction of the magic formula or the creation of Jura) constitutes an important turning point for the entire set of referenda. It is also obvious that the total percentage of the variance explained by all three factors together, as well as the percentage of the variance explained by the homogeneity factor, increased dramatically in the "after" periods of these events.

As Jura was established only 20 years and 106 referenda after the introduction of the magic formula, it is difficult to accurately evaluate its impact. It is easier however to try and assess the independent impact of the magic formula. Table 4 presents the percentage of variance explained by the three factors after the introduction of the magic formula and before the creation of Jura.

The results shown in Table 4 indicate clearly that the magic formula by itself is responsible for most of the increase in both the total variance explained by all three factors together, and especially for most of the increase in the variance explained by the homogeneity factor.

The additional increase in the total explanation and in the weight of the homogeneity factor $(0.898 \%$ and $0.835 \%$, respectively) should be attributed to the creation of Jura. It also transpires that the establishment of Jura increased appreciably the impact of the language factor and decreased the impact of the second heterogeneity factor (by $+4.748 \%$ and $-4.685 \%$ respectively).

From all the above it follows that the answers to our third and fourth questions are that linguistic differences have become more prominent since the establishment of Jura in 1979, and that the homogeneity factor has become more prominent since the implementation of the magic formula agreement in 1959. Furthermore, the establishment of Jura also contributed, in a marginal way, to the homogeneity factor.

Table 5 presents the percent of variance explained by each of our three factors in each of the three types of referenda. The total variance 
TABLE 2

Percentage Variance Explained Before and After the Creation of Canton of Jura

\begin{tabular}{lcccc}
\hline \hline & $\begin{array}{c}\text { Percentage Variance } \\
\text { Explained by } \\
\text { Number of Referenda }\end{array}$ & $\mathrm{N}$ & $\begin{array}{c}\text { Percentage Variance } \\
\text { Explained by } \\
\text { Language Factor }\end{array}$ & $\begin{array}{c}\text { Percentage Variance } \\
\text { Explained by Second } \\
\text { Heterogeneity Factor }\end{array}$ \\
\hline Before: $2-303$ & 302 & 68.227 & 5.805 & 11.408 \\
After: $304-538$ & 235 & 84.576 & 7.655 & 2.346 \\
\hline
\end{tabular}

TABLE 3

Percentage Variance Explained Before and After the Institution of the Magic Formula

\begin{tabular}{|c|c|c|c|c|c|}
\hline Number of Referenda & $\mathrm{N}$ & $\begin{array}{l}\text { Percentage Variance } \\
\text { Explained by } \\
\text { Homogeneity Factor }\end{array}$ & $\begin{array}{l}\text { Percentage Variance } \\
\text { Explained by } \\
\text { Language Factor }\end{array}$ & $\begin{array}{l}\text { Percentage Variance } \\
\text { Explained by Second } \\
\text { Heterogeneity Factor }\end{array}$ & $\begin{array}{c}\text { Total Percentage } \\
\text { Variance Explained }\end{array}$ \\
\hline Before: $2-197$ & 196 & 61.782 & 6.358 & 14.296 & 82.435 \\
\hline After: $198-538$ & 341 & 84.576 & 7.655 & 2.346 & 94.577 \\
\hline
\end{tabular}


TABLE 4

Percentage of Variance Explained During the Period between the Institution of the Magic Formula and the Creation of Canton of Jura

\begin{tabular}{|c|c|c|c|c|c|}
\hline Number of Referenda & $\mathrm{N}$ & $\begin{array}{l}\text { Percentage Variance } \\
\text { Explained by } \\
\text { Homogeneity Factor }\end{array}$ & $\begin{array}{c}\text { Percentage Variance } \\
\text { Explained by } \\
\text { Language Factor }\end{array}$ & $\begin{array}{l}\text { Percentage Variance } \\
\text { Explained by Second } \\
\text { Heterogeneity Factor }\end{array}$ & $\begin{array}{c}\text { Total Percentage } \\
\text { Variance Explained }\end{array}$ \\
\hline $198-303$ & 106 & 83.741 & 2.907 & 7.031 & 93.679 \\
\hline Distance from respective "after" value in Table 3 & - & -0.835 & -4.748 & +4.685 & -0.898 \\
\hline
\end{tabular}

TABLE 5

Percentage of Variance Explained by Type of Referenda

\begin{tabular}{lcccc}
\hline \hline & Percentage Variance & Explained By \\
Type of Referenda & $\mathrm{N}$ & Homogeneity Factor & $\begin{array}{c}\text { Percentage Variance } \\
\text { Explained By } \\
\text { Language Factor }\end{array}$ & $\begin{array}{c}\text { Explained By Second } \\
\text { Heterogeneity Factor }\end{array}$ \\
\hline 1 & 186 & 81.542 & 9.082 & 2.197 \\
$2 \mathrm{a}$ & 154 & 74.188 & 14.483 & 4.113 \\
$2 \mathrm{~b}$ & 197 & 81.739 & 8.504 & 3.762 \\
\hline
\end{tabular}


TABLE 6

Number and Percentage of Passed and Failed

Proposals by Type of Referenda

\begin{tabular}{lrcr}
\hline \hline Type of Referenda & N & Proposals Passed & Proposals Failed \\
\hline 1 & 186 & $140(75.3 \%)$ & $46(24.7 \%)$ \\
$2 \mathrm{a}$ & 154 & $82(53.2 \%)$ & $72(46.8 \%)$ \\
2b & $197 *$ & $34(17.3 \%)$ & $163(82.7 \%)$ \\
Total & 537 & $256(47.7 \%)$ & $281(52.3 \%)$ \\
\hline
\end{tabular}

*Note: These 197 cases include the 33 cases in which there was a counterproposal to the initiative.

explained by all the three factors together is almost identical for each of the three referenda types. At the same time, the results show that the homogeneity factor is more prominent in referenda of types 1 and $2 b$ than in referenda of type 2a. Conversely, the impact of the language factor is much stronger in referenda of type $2 \mathrm{a}$. In other words, voting behaviour is more homogeneous over cantons when constitutional matters are at stake, regardless of whether the referenda were initiated by the government or by the public.

Based on the data presented in the bottom line of Appendix B, Table 6 demonstrates that the government tends to be most successful by far when constitutional issues are at stake. In referenda of type 1 it succeeded in 75.3 per cent of the cases. In referenda of type $2 b$ its success is even higher: 82.7 per cent. But in facultative referenda (of type 2a) the rate of governmental success shrinks to 46.8 per cent only. ${ }^{24}$

The findings depicted in Tables 5 and 6 suggest the possibility that the homogeneous factor is stronger (that is, accounts for a larger percentage of the observed variance) within each type of referenda when the overall outcome of a referendum is concordant with the government's position than when this outcome constitutes a rejection of the government's position. Table 7 shows that this is indeed true for all three types of referenda, as well as that the impact of the two heterogeneity factors (language and the second heterogeneity factor) increase, within each type of referenda, when the government's position is rejected.

Finally, we wish to note that the rate of participation in Swiss referenda-regardless of type-decreased over time. Pearson's coefficient of linear correlation between the year a referendum was conducted and the overall turnout in that referendum was always negative: -0.545 for all types of referenda combined, -0.461 for referenda of type $1,-0.692$ for referenda of type $2 \mathrm{a}$, and -0.511 for referenda of type $2 b^{25}$ There are probably several reasons which may explain the decrease in the rate of participation over the years, but the most likely 
TABLE 7

Percentage of Variance Explained by Type of Referenda and Governmental Success/Failure

\begin{tabular}{|c|c|c|c|c|c|}
\hline $\begin{array}{l}\text { Type of Referenda } \\
\text { and Governmental } \\
\text { Success/Failure }\end{array}$ & $\mathrm{N}$ & $\begin{array}{c}\text { Percentage Variance } \\
\text { Explained Homogeneity } \\
\text { Factor }\end{array}$ & $\begin{array}{c}\text { Percentage Variance } \\
\text { Explained Language } \\
\text { Factor }\end{array}$ & $\begin{array}{l}\text { Percentage Variance } \\
\text { Explained Second } \\
\text { Heterogeneity Factor }\end{array}$ & $\begin{array}{c}\text { Total Percentage } \\
\text { Variance Explained }\end{array}$ \\
\hline Type 1 success & 140 & 74.438 & 9.799 & 3.695 & 87.932 \\
\hline Type 1 failure & 46 & 57.261 & 19.417 & 7.959 & 84.637 \\
\hline Type $2 \mathrm{a}$ success & 72 & 58.324 & 23.521 & 8.788 & 90.632 \\
\hline Type $2 \mathrm{a}$ failure & 82 & 62.495 & 18.745 & 6.495 & 87.735 \\
\hline Type $2 \mathrm{~b}$ success & 163 & 70.129 & 14.479 & 6.107 & 90.715 \\
\hline Type $2 b$ failure & 34 & 58.808 & 19.752 & 11.364 & 89.924 \\
\hline
\end{tabular}


one is the significant growth over time in the number of referenda conducted per year which causes citizens to become weary or apathetic with this instrument of direct democracy. ${ }^{26}$

Thus it seems quite likely that the increase in the importance of both the homogeneity and language factors since the adoption of the magic formula, as well as the decrease in the importance of the second heterogeneity factor (see Table 3), is not only due to the institution of the magic formula, but also to the decrease in the rate of participation in Swiss referenda.

It is also interesting to note that over the years there is evidence of a slight growth in the ability of the government to maintain its position in referenda of type 1 , a slight decrease in its ability to maintain its position in referenda of type $2 \mathrm{a}$, and almost no change in its ability to maintain its position regarding referenda of type $2 \mathrm{~b}$ : Pearson's linear correlation coefficient between the year a referendum was conducted and the overall proportion of "yes" votes is 0.216 for referenda of type 1 , whereas Pearson's correlation coefficient between the year a referendum was conducted and the overall proportion of "no" voters was -0.284 and 0.071 for referenda of types $2 \mathrm{a}$, and $2 \mathrm{~b}$, respectively.

The institution of the magic formula also serves as a significant turning point in the extent of decisiveness of the various Swiss referenda that were conducted before and after this event. If we denote by $x$ and $y$ the total number of voters who voted "yes" and "no," respectively, in a given referendum, then the extent of decisiveness in that referendum, denoted $\mathrm{D}$, is given by the formula: $\mathrm{D}=|(x-y)| /(x+y)$.

As can be seen from Table 8 , the mean and median decisiveness of the referenda conducted before and after the institution of the magic formula depends on the type of the referenda as well as on whether the proposal was ultimately accepted or rejected. Except for referenda of type $2 \mathrm{~b}$, the difference between the extent of decisiveness, both before and after the institution of the magic formula, is larger for referenda that passed than for referenda which failed to pass.

For referenda of types 1 and $2 \mathrm{a}$ which passed, their extent of decisiveness was larger after the institution of the magic formula than before, and the same is true for referenda of type $2 b$ which failed to pass. These results imply that in all three types of referenda where the government's position was adopted, the mean margin of victory attained was higher after the institution of the magic formula than before its institution. Conversely, in all three types of referenda where the government's position was rejected, the mean decisiveness attained was higher before the institution of the magic formula than after its institution.

In this context we should also like to mention the study by Sciarini and Trechsel (1996) who investigated the connection, during the period 1947 to 1995, between the extent of support in the lower house of the 
TABLE 8

Mean, Median, and Standard Deviation (S.D) of (Relative)

Decisiveness (D) between Overall "Yes" and "No" Votes in Swiss

Referenda Conducted Before and After the Institution of the Magic

Formula (MF) by Type of Referenda and Outcome

\begin{tabular}{lrccc}
\hline \hline Type of Referenda & N & Mean & Median & S.D \\
\hline All referenda that passed before MF & 88 & 0.302 & 0.270 & 0.194 \\
All referenda that passed after MF & 168 & 0.334 & 0.318 & 0.207 \\
All referenda that failed before MF & 108 & 0.275 & 0.229 & 0.212 \\
All referenda that failed after MF & 173 & 0.274 & 0.276 & 0.187 \\
Type 1 referenda that passed before MF & 50 & 0.334 & 0.301 & 0.189 \\
Type 1 referenda that passed after MF & 90 & 0.404 & 0.393 & 0.205 \\
Type 1 referenda that failed before MF & 24 & 0.137 & 0.142 & 0.099 \\
Type 1 referenda that failed after MF & 22 & 0.135 & 0.105 & 0.128 \\
Type 2a referenda that passed before MF & 23 & 0.199 & 0.134 & 0.162 \\
Type 2a referenda that passed after MF & 59 & 0.237 & 0.214 & 0.167 \\
Type 2a referenda that failed before MF & 41 & 0.234 & 0.179 & 0.186 \\
Type 2a referenda that failed after MF & 31 & 0.198 & 0.145 & 0.146 \\
Type 2b referenda that passed before MF & 15 & 0.351 & 0.381 & 0.206 \\
Type 2b referenda that passed after MF & 19 & 0.303 & 0.254 & 0.206 \\
Type 2b referenda that failed before MF & 43 & 0.391 & 0.351 & 0.223 \\
Type 2b referenda that failed after MF & 120 & 0.320 & 0.319 & 0.188 \\
\hline
\end{tabular}

federal parliament for a certain proposal, which thereafter was submitted to a referendum, and this proposal's chance to pass in the referendum. The authors of this study discovered that the support in the federal parliament for proposals that were ultimately submitted to referenda of types $1,2 \mathrm{a}$, and $2 \mathrm{~b}$, were, on average, 80,90 , and 20 per cent, respectively. They also found that governmental proposals to revise the constitution (that were submitted to referenda of type 1) had only a probability of 0.3 to be approved by the people when the federal parliament was highly divided about them, and a probability of 0.7 of being approved by the people if they enjoyed at least an 80 per cent support in the federal parliament. The chance of a constitutional initiative (submitted to a referendum of type $2 b$ ) to be approved by the people is negligible if this initiative was rejected by the federal parliament, but if it was supported by 50 per cent of the members of the federal parliament its chance of being approved by the people was also about 50 per cent. As for laws that were submitted to a facultative referendum (type 2a), a direct connection was found between the extent of support the law gained originally in the federal parliament and the chance that citizens will succeed in collecting the necessary number of signatures to submit this law to a referendum. However, given that the necessary number of signatures has been collected, no connection was found between the level of support the law received 
in the federal parliament and its chance of being approved or rejected by the people in the facultative referendum. In view of these findings the authors conclude that there is no proof that the federal parliament loses control over the political process as a result of the various referenda.

\section{Discussion}

During the last two decades a growing number of veteran and new democracies decided to employ referenda as a tool of direct democracy (see, for example, Butler and Ranney, 1994; Qvortrup, 2002; LeDuc, 2003; Kaufman and Waters, 2004). This new trend should be evaluated against the potential dangers associated with referenda, especially in heterogeneous societies (see Haskell, 2000).

In view of this, it seems to us that the examination of the Swiss case is crucial. Switzerland is an exceptionally heterogeneous polity. It is unique not only in that it conducted to date a total number of national referenda larger than that conducted in any other country, but also in the fact that in no other country do citizens, not just the government, actually exercise their right to initiate a referendum to amend the constitution. Although during recent decades many European countries have incorporated in their constitutions explicit articles regarding the situations in which a referendum must be conducted, ${ }^{27}$ the kind of situations and number of issues on which national referenda can or must be conducted in Switzerland is considerably larger.

As stated by Kriesi $(1995: 80-81,88)$, the broad use of instruments of direct democracy by the Swiss federation has affected its political system more than in any other country that uses such instruments, and referenda have contributed significantly to the integration of its social and political forces. Although the broad employment of referenda curtails the maneuverability of both the government and federal parliament and slows the legislative process, it increases considerably the legitimacy of decisions made by these institutions because they are more easily accepted by those who lost in some referendum.

At the beginning of this study we posed the question whether voting behaviour in a pluralistic society that uses measures of direct democracy tends to reflect more the heterogeneous or the homogeneous characteristics of this society. Based on the Swiss experience the answer seems quite clearly that the use of such measures tends to reflect much more the homogeneous characteristics of a pluralistic society than its heterogeneous ones. Eschet-Schwarz (1989) claimed that the referenda apparatus instituted in Switzerland serves as the cement that holds this heterogeneous society together. This study proves that heterogeneity and referendums go hand in hand in Switzerland, but at the same time one 
must remember that there are many divided yet stable societies elsewhere that do not rely on referenda. Furthermore, in some divided political systems it seems that referenda contributed negatively to national as well as democratic stability.

By looking at the entire data set of Swiss referenda results, it is clear that the fear of frequent events where overwhelming majorities in German-speaking cantons would confront sizable majorities in Frenchand Italian-speaking cantons did not materialize, and such events occurred only rarely. In fact - and perhaps somewhat surprisingly - there were some instances during the period 1870-1920, which was a crucial period for the Swiss nation-building, that the French- and Italian-speaking cantons possessed veto powers (Kriesi et al., 1996: 30-32).

Our data clearly reveal that the political behaviour in national referenda among the various cantons becomes more and more similar as time elapses. This may be attributed to the gradual development of real community that was established progressively in Switzerland, which possesses increasingly shared values beyond the cantonal or regional identities. The growing similarity in patterns of political behaviour fosters the development of a common culture, which in turn helps to reduce the salience of cleavages (Kriesi et al., 1996: 49, 55-56). Nevertheless, one must remember that the creation of common culture, and the tendency toward more integration of the Swiss community, is in no way an attempt to transform the Swiss society into a homogeneous society.

The increasing similarity in the cantons' political behaviour in referenda is not attributed only to the decline of the cleavages, but could be attributed also to multiple institutional adaptations instituted by the Swiss authorities along all periods, as well as the result of appropriate evolution of the referendum mechanism itself. Among these elements one can mention the extensive consultation with all the relevant interest groups before adopting a bill by parliament, conducting a referendum on a counterproposal submitted by the government if a referendum on a proposal submitted by the people cannot be avoided, as well as reaching the magic formula agreement (Papadopoulos, 2001: 38-46).

Nevertheless, it would also seem that the rather large number of referenda to which Swiss citizens are exposed results in a rather low participation rate: out of the 519 national referenda conducted since 1879 (referendum \#20), the overall rate of participation in 340 of them was less than 50 per cent, and only in seven referenda the overall majority of voters constituted also an overall majority of the eligible voters. ${ }^{28}$ This should definitely give the Swiss people food for thought about mitigating their use of this instrument of direct democracy.

As clear as the results in the Swiss case seem to be, many questions about the impact of the referendum apparatus at large remain open: Are referendums required because of consensualism, or is consensualism 
of this extent only possible with referendums? ${ }^{29}$ Which of the two advantages of referendums is more important: legitimacy or making hard decisions? What should be the proper balance between referendum, the legislative and the executive in different democratic societies? One lesson that can be drawn from the present study is that the answers to such questions are not simple and should be based on solid theoretical and empirical grounds. ${ }^{30}$

\section{Notes}

1 Lijphart (1984: 43) defines a heterogeneous society (for the 21 countries he investigated) as one where less than 80 per cent of the population belongs to the same religious or linguistic group.

2 Pipa Norris (2004: 228), however, argues that representation of minorities can be safeguarded also in majoritarian electoral systems provided that adequate arrangements are in place, for example, establishing quotas for some minority segments. Similarly, Guinier (1994) proposes increasing the influence of minorities within majoritarian systems by requiring super-majorities to pass decisions, or by instituting (majoritarian) electoral procedures that foster representation of minorities, for example, cumulative voting.

3 It should be mentioned that, from the point of view of social choice theory, direct democracy has two main advantages over representational democracy: the a priori voting power of a voter in direct democracy is significantly larger than in a representational democracy; also, it is possible that, other things being equal, in representational democracy the voting outcome in parliament on some issue is contrary to the wishes of the majority of the people, that is, it is contrary to the outcome that would have been obtained in a referendum (this phenomenon is called "majority deficit"). On these issues see Felsenthal and Machover (1998, chap. 3).

4 According to Kaufman and Waters (2004: 139-140), 71 referenda were conducted in the world during the nineteenth century of which 57 were conducted in Switzerland; during the period 1900-2003, 1281 referenda were conducted in the world of which 465 (national) referenda were conducted in Switzerland, and of all the 738 referenda conducted in the world between 1970 and 2003, 297 (national) referenda were conducted in Switzerland. Katz and Koole (2002: 890-896) who surveyed 33 democracies for the period 1991-2001, show that Switzerland led the list in terms of number of years (11) within this 11-year period in which referenda were conducted. It was followed by Ireland (8), New Zealand (5), Denmark and Italy (4), Slovakia (3), France and Poland (2), Austria, Canada, Finland, Norway, Portugal and Sweden (1). In all other 19 democracies surveyed no referendum was conducted during the investigated period.

5 The distribution of Swiss cantons by the language and religion of the majority of their citizens did not change during the years, although the sizes of these majorities has decreased with time. Thus, for example, 93 per cent of the citizens of Zürich in 1870 were Protestants, and this percentage has decreased to 63 per cent in 1983.

6 During the period 1959-2003 three of the four parties, that is, the Christian Democratic People's Party, Social Democratic Party, and Radical Free Democratic Party, held each two cabinet portfolios, while the Swiss People's Party — which was the largest of the four parties since 1999-held only one portfolio. Since 2003 the Swiss People's Party has held two portfolios, while the Christian Democratic People's Party became the smallest of these four parties and therefore held only one portfolio. It 
should be noted that the starting point of progressive steps toward the realization of the magic formula commenced in 1891 when the representative of the Catholic conservatives joined the government (see Bolliger and Zürcher, 2004).

7 The difference between these two numbers is due to the fact that, as we explain regarding popular initiatives, the government submitted counterproposals to the proposals submitted by the citizens 15 times. In 13 of these times (all occurring prior to 1987) the voters voted simultaneously on the original proposal and on the counterproposalwhich we counted as 26 separate referenda instead of just 13; and in the remaining two of these times the voters could also vote on a third "deciding" question, namely, which of the two proposals should be adopted in case both received the required majority - which we counted as six referenda instead of just two.

8 As stated earlier, the Swiss federation was composed of 25 cantons during the period 1848 to 1978 , and of 26 cantons since Jura was created in 1979. The name of each canton in this paper is given in the language of the majority of its citizens.

9 For the first 19 referenda (conducted during the period 1848-1877) this datum was available only for some of the cantons. Consequently the correlations in this study involving overall rate of participation are based only on 519 referenda conducted since 1879 .

10 Schaffhausen is the only canton where (according to Article 23(2) of its constitution) voting is still mandatory and a voter who unjustifiably fails to vote is liable to pay a 3 CHF fine. Church (2004: 134, 141) erroneously asserts that Schaffhausen has recently abolished this requirement.

11 This is pertinent for those referenda in which double-majority is required for passing proposals - see below.

12 In the 1872 attempt to revise the constitution it was proposed to give the legislatures of just five cantons the power to initiate a facultative referendum. This proposal failed to pass because it was feared that the seven Catholic cantons who participated in the 1847 Sonderbund civil war might take advantage of it. Hence in the 1874 revised constitution the number of cantons' legislatures needed to initiate a facultative referendum was raised to eight (see Grisel, 1997: 298). It is interesting to note that the first and only time the cantons' legislatures actually exercised this privilege of initiating a facultative referendum (which ultimately failed to pass) was in referendum \#509 (May 2004).

13 So far this has happened only once-in referendum 122 (1935).

14 So far there were only two such cases - referendum 234 (1973) and referendum 277 (1977).

15 So far there were four such referenda-134 (1941), 157 (1951), 213 (1966), 255 (1976).

16 In referenda 82 (1920), 107 (1929), 126 (1938), 156 (1951), 174 (1955), 227 (1972), 232 (1972), 245 (1974), 256 (1976), 267 (1977), 270 (1977), 311 (1982), 339 (1986).

17 In referenda 465 (2000) and 489 (2002).

18 This happened in referenda 69 (1908), 112 (1931), 130 (1939), 139 (1945), 140 (1946), 179 (1956), 187 (1958), 294 (1979), 306 (1981), 307 (1981), 325 (1984), 336 (1985), 342 (1986), 379 (1992), 419 (1995), 431 (1996), 466 (2000), 504 (2004).

19 Until 1979 there were 19 cantons with one vote each and six cantons with half a vote each, and since 1979 there is an additional canton (Jura) having one vote. A canton's vote (weight) is presumed to be cast in favour of the response ("yes" or "no") supported by the majority of its voters. The cantons with half a vote were created at various dates during Swiss history when three full cantons were each subdivided, for various reasons, into two half-cantons: the canton of Unterwalden (which was one of the three original cantons forming the Swiss League in 1291) was subdivided into the (half) cantons of Obwalden and Nidwalden; Basel (which joined the Swiss Confederation in 1501) was subdivided in 1833 into the (half) cantons of Basel-City and Basel-Country; and Appenzell (which joined the Swiss Confederation in 1513) was 
subdivided in 1597 into the (half) cantons of Appenzell Outer Rhodes and Appenzell Inner Rhodes. Each of these six half-cantons has only one representative in the Council of States (Ständerat) whereas a full canton has two representatives.

20 The six referenda of type 1 are \#2 (1866), 223 (1970), 246 (1975), 313 (1983), 410 (1994), 411 (1994), and the two referenda of type 2b are \#174 (1953) and 234 (1973).

21 It should be noted that in each cell in the first 26 columns of our basic table we could have entered other data such as frequencies of "yes" answers, proportion of "yes" responses out of all eligible voters, or proportion of "yes" responses out of all actual voters (including those who cast blank and invalid votes). We considered the alternative chosen as the most appropriate for our purposes. Of course, future research may examine any of the other alternatives as well as extend our investigation to include also referenda conducted in the commune and/or canton level.

22 For the sake of consistency, we used the same version of factor analysis in Tables 1-5 and 7 , that is to say, principal component analysis and three orthogonal factors. Although we tried other versions as well-for example, letting the factor analysis SPSS program choose the number of factors and/or the employment of oblique factors - we adopted this most common version because alternative factor analyses all resulted in substantially similar findings. Furthermore, because of obvious theoretical considerations "homogeneity" and any aspect of "heterogeneity" should be regarded as orthogonal, while the two issues of language and religion are orthogonal due to the factual background depicted in Appendix A.

23 The cleavage along religious lines was strong until the First World War, but became considerably weaker since then due, among other things, to the decreasing importance of religion in daily life (reflected in the decreasing number of people who view themselves as religious), as well as a result of internal migration - especially migration of persons from rural Catholic cantons to large (and mainly Protestant) cities. It therefore seems to us that this second heterogeneity factor includes the remaining effects of the religious cleavage, as well as additional factors such as conservatism versus liberalism, agrarianism versus industrialism and a strong services sector, and urban versus rural characteristics.

24 It should be noted that only a relatively low percentage of the laws that were passed by the federal parliament were subject to such referenda (6.9 per cent of the laws passed during the period 1874-1994, and 5.9 per cent of the laws passed during the period 1947-1995). See Sciarini (1999: 625).

25 These correlations are based on 519 referenda beginning with referendum \#20. This is so because only from this referendum onwards there exists, for each referendum, data regarding both the rate of participation in every canton as well as in Switzerland at large.

26 It should be noted that about 50 per cent of all Swiss referenda were conducted during the last 30 years whereas the remaining 50 per cent were spread over a period of (the preceding) 128 years; since the year 2000 at least five referenda were conducted every year.

27 At the time of writing (July 2006), of all central and western European countries that have constitutions, only those of Belgium, Germany, the Netherlands and Norway lack an article specifying when a referendum can or must be conducted (see Kaufman and Waters, 2004: 33-117).

28 This happened in referenda \# 53 (1898), 74 (1915), and 147 (1947)—where the overall majority of the voters voted "yes," as well as in referenda \# 35 (1891), 43 (1894), 93 (1922), and 107 (1929) — where the overall majority of the voters voted "no."

29 McRae (1997) provides a partial answer to this question by stating that some features of consensual attitudes and amicable agreements existed a long time before the creation of the modern Swiss federation in 1848. Beside these features a partial semidirect democracy and Landsgemeinden was functioning. 
30 It should be emphasized that because Switzerland is unique, the implications for normative theories may be far from apparent.

\section{References}

Bartolini, Stefano and Peter Mair. 1990. Identity, Competition, and Electoral Availability. Cambridge: Cambridge University Press.

Bartolini, Stefano. 2000. The Political Mobilization of the European Left, 1860-1980: The Class Cleavage. Cambridge: Cambridge University Press.

Bolliger, Christian and Regula Zürcher. 2004. "Deblockierung durch Kooptation? Eine Fallstudie zur Aufnahme der Katolisch-Konservativen in die Schweizerische Landesregierung 1891." Swiss Political Science Review 10(4): 59-92.

Butler, David, and Austin Ranney, eds. 1994. Referendums around the World: The Growing Use of Direct Democracy. Washington, DC: American Enterprise Institute for Public Policy Research.

Church, Clive H. 2004. The Politics and Government of Switzerland. New York: Palgrave Macmillan.

Eschet-Schwarz, André. 1989. "The Role of Semi-Direct Democracy in Shaping Swiss Federalism: The Behavior of Cantons Regarding Revision of the Constitution." Publius 19: 79-106.

Felsenthal, Dan S. and Moshé Machover. 1998. The Measurement of Voting Power: Theory and Practice, Problems and Paradoxes. Cheltenham, UK: Edward Elgar.

Gerber, Elizabeth R. 1999. The Populist Paradox: Interest Group Influence and the Promise of Direct Legislation. Princeton: Princeton University Press.

Grisel, Etienne. 1997. Initiative et Référendum Populaires. 2nd ed. Berne: Staempfli.

Guinier, Lani. 1994. The Tyranny of the Majority: Fundamental Fairness in Representative Democracy. New York: Free Press.

Haskell, John. 2000. Direct Democracy or Representative Government? Dispelling the Populist Myth. Boulder, CO: Westview Press.

Jung, Sabine. 1996. "Lijpharts Demokrtatietypen und die Direkte Demokratie." Zeitschrift für Politikwissenschaft 6(3): 623-45.

Katz, Richard S. and Ruud Koole. 2002. "Political Data in 2001." European Journal of Political Research 41: 885-96.

Kaufman, Bruno, and M. Dane Waters, eds. 2004. Direct Democracy in Europe: A Comprehensive Reference Guide to the Initiative and Referendum Process in Europe. Durham: Carolina Academic Press.

Kriesi, Hanspeter. 1995. Le Système Politique Suisse. Paris: Economica.

Kriesi, Hanspeter, Ruud Koopmans, Jan Willem Duyvendak and Marco G. Giugni. 1995. New Social Movements in Western Europe: A Comparative Analysis. Minneapolis: University of Minnesota Press.

Kriesi, Hanspeter, Boris Vernli, Pascal Sciarini and Matteo Gianni. 1996. Le Clivage Linguistique : Problèms de Compréhension entre les Communautés Linguistiques en Suisse. Berne, Office Fédéral de la Statistique.

LeDuc, Lawrence. 2003. The Politics of Direct Democracy: Referendums in Global Perspective. Peterborough, ON: Broadview Press.

Lijphart, Arend. 1984. Democracies: Patterns of Majoritarian and Consensus Government in Twenty-One Countries. New Haven, CT: Yale University Press.

Lijphart, Arend. 1999. Patterns of Democracy: Government Forms and Performance in Thirty-Six Countries. New Haven, CT: Yale University Press.

Linder, Wolf. 1998. Swiss Democracy. 2nd ed. New York: St Martin's Press.

Lipset, Seymour Martin. 1981. Political Man: The Social Bases of Politics. Baltimore: Johns Hopkins University Press. 
McRae, Kenneth D. 1983. Conflict and Compromise in Multilingual Societies: Switzerland. Waterloo, ON: Wilfrid Laurier University Press.

McRae, Kenneth D. 1986. Conflict and Compromise in Multilingual Societies: Belgium. Waterloo, ON: Wilfrid Laurier University Press.

McRae, Kenneth D. 1997. "Contrasting Styles of Democratic Decision-Making: Adversarial versus Consensual Politics." International Political Science Review 38(3): 279-95.

Norris, Pipa. 2004. Electoral Engineering. New York: Cambridge University Press.

Papadopoulos, Yannis. 1998. Démocratie Directe. Paris: Economica.

Papadopoulos, Yannis. 2001. "How Does Direct Democracy Matter? The Impact of Referendum Votes on Politics and Policy-Making." West European Politics 24(2): 35-58.

Pichard, Alain. 2004. La Question Jurassienne. Lausanne: Presses Polytechniques et Universitaires Romandes.

Qvortrup, Mads. 2002. A Comparative Study of Referendums: Government by the People. Manchester: Manchester University Press.

Sciarini, Pascal. 1999. "La Formulation de la Décision." In Handbuch der Schweizer Politik, ed. Ulrich Klöti, Peter Knoepfel, Hanspeter Kriesi, Wolf Linder, and Yannis Papadopoulos. Zürich: Neue Züricher Zeitung Verlag.

Sciarini, Pascal and Alexandre H. Trechsel. 1996. "Démocratie Directe en Suisse: L'élite Politique Victime des Droits Populaires?" Swiss Political Science Review 2: 201-32. Setälä, Maija. 1999. Referendums and Democratic Government. London: Macmillan. 
APPENDIX A

Distribution of Swiss Cantons by Language and Religion of the Majority and the Number and Percentage of Referenda in Which a Canton's Majority Position Agreed with the Final Outcome

\begin{tabular}{|c|c|c|c|c|}
\hline Canton & $\begin{array}{l}\text { Majority's } \\
\text { Language }\end{array}$ & $\begin{array}{l}\text { Majority's } \\
\text { Religion }\end{array}$ & $\begin{array}{c}\text { \# Referenda } \\
\text { Canton's Position } \\
\text { Agreed with } \\
\text { Final Outcome }\end{array}$ & $\begin{array}{c}\% \text { Referenda } \\
\text { Canton's Position } \\
\text { Agreed with } \\
\text { Final Outcome }\end{array}$ \\
\hline$\overline{Z u g}$ & German & Catholic & 496 & 92.36 \\
\hline Luzern & German & Catholic & 495 & 92.18 \\
\hline Bern & German & Protestant & 488 & 90.88 \\
\hline St. Gallen & German & Catholic & 478 & 89.01 \\
\hline Aargau & German & Protestant & 477 & 88.83 \\
\hline Solothurn & German & Catholic & 477 & 88.83 \\
\hline Schaffhausen & German & Protestant & 471 & 87.71 \\
\hline Basel Land & German & Protestant & 464 & 86.41 \\
\hline Nidwalden & German & Catholic & 463 & 86.22 \\
\hline Graubünden & German & Protestant & 460 & 85.66 \\
\hline Zürich & German & Protestant & 460 & 85.66 \\
\hline Appenzell A.-Rh. & German & Protestant & 457 & 85.10 \\
\hline Glarus & German & Protestant & 457 & 85.10 \\
\hline Uri & German & Catholic & 456 & 84.92 \\
\hline Thurgau & German & Protestant & 454 & 84.54 \\
\hline Obwalden & German & Catholic & 448 & 83.43 \\
\hline Fribourg & French & Catholic & 438 & 81.56 \\
\hline Schwyz & German & Catholic & 434 & 81.82 \\
\hline Vaud & French & Protestant & 434 & 80.82 \\
\hline Basel Stadt & German & Protestant & 430 & 80.07 \\
\hline Ticino & Italian & Catholic & 427 & 79.52 \\
\hline Appenzell I.-Rh & German & Catholic & 424 & 78.96 \\
\hline Valais & French & Catholic & 426 & 79.33 \\
\hline Neuchâtel & French & Protestant & 412 & 76.72 \\
\hline Genève & French & Catholic & 408 & 75.98 \\
\hline Jura & French & Catholic & 167 & $71.06^{*}$ \\
\hline
\end{tabular}

*Note: Jura participated since its creation in 1979 in only 235 of the 537 referenda. 


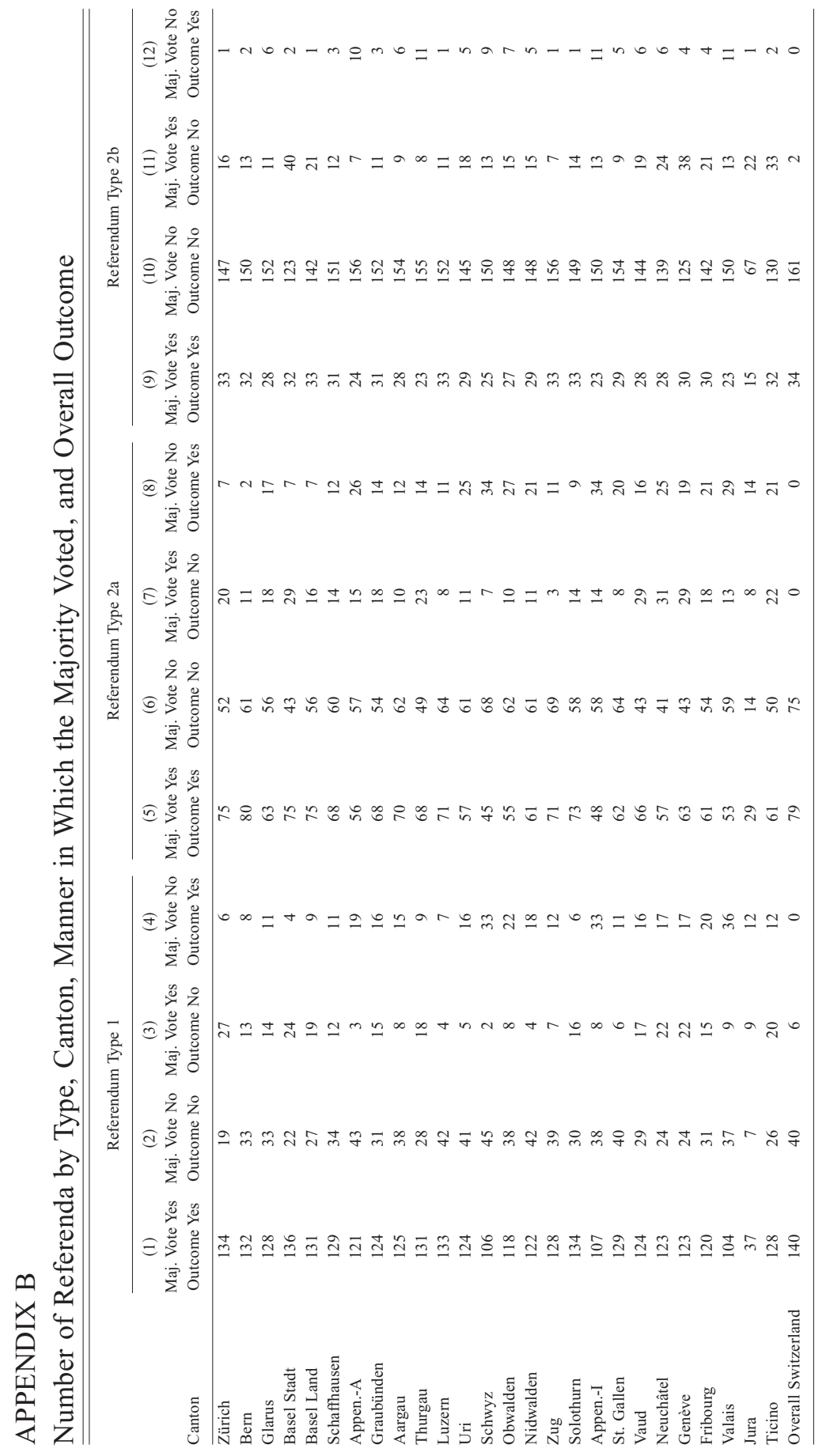

